\title{
A Future Look
}

Eduardo Mario Dias ${ }^{\mathrm{a}}$, Eduardo Facchini ${ }^{\mathrm{b}}$, Antônio Carlos de Moraes $^{\mathrm{c}}$, Mauricio Lima Ferreira ${ }^{\mathrm{d}}$, Willian Reginato Este ${ }^{\mathrm{e}}$, Maria Lídia Rebello Pinho Dias ${ }^{\mathrm{f}}$

\footnotetext{
${ }^{a}$ Affiliation - Research group coordinator *GAESI USP - Escola Politécnica da Universidade de São Paulo emdias@pea.usp.br

${ }^{\mathrm{b}}$ Affiliation - *GAESI researcher of the research group USP - Escola Politécnica da Universidade de São Paulo eduardofacchini@globo.com

'Affiliation - Professor - PUC - Pontifícia Universidade Católica de Sãs Paulo - mouraria@pucsp.br

${ }^{\mathrm{d}}$ Affiliation - *GAESI researcher of the research group USP - Escola Politécnica da Universidade de São Paulo mauriciolf@uol.com.br

${ }^{\text {e} A f f i l i a t i o n ~-~ * G A E S I ~ r e s e a r c h e r ~ o f ~ t h e ~ r e s e a r c h ~ g r o u p ~ U S P ~-~ E s c o l a ~ P o l i t e ́ c n i c a ~ d a ~ U n i v e r s i d a d e ~ d e ~ S a ̃ o ~ P a u l o ~-~}$ willianre@hotmail.com

${ }^{\mathrm{f}}$ Affiliation - *GAESI researcher of the research group USP - Escola Politécnica da Universidade de São Paulo lidiadias@pea.usp.br
}

*GAESI is a group of applied research and development of solutions born in the Department of Energy Engineering and Electrical Automation at USP's Polytechnic School.

The Group is composed of experts who develop projects and training in Management of Public and Private Process Automation. (Management Automation and IT)

Technology, Man, Machine, Unemployment, Profit

\section{ABSTRACT}

Since the Industrial Revolution, some believe that the machines will take the place of men, their simplest task to the most sophisticated. Others, that technology has transformed the habits of society and improves his quality of life. This article debates the technology and its relationship with the man, the automation of human occupations and the impact on their daily lives.

Although the issue travels in the realm of science fiction, the man faces specifically with the machine in carrying out their professional activities, in meeting their reproductive needs, including entertainment. To address this issue, it was essential to recover the debate on the Law of Declining Trend Profit formulated by Karl Marx in Capital Rate and illustrates, recover the work of Isaac Asimov's fiction, I, Robot.

\section{Introduction}

There is a new form of communication between the new machines, alien to the majority of its members where hardware and software are communicating through transmission technologies, computing, protocols and power using small batteries that allow communication between machines and routine processes of our daily lives.

Everything is related to the capture of information that is sensitive and useful to us humans as: location, light, noise, temperature, biometrics, altitude, motion, speed, images, stock level and everything that can be measured by the sensors. All too often is connected to data networks through antennas of various standards 
or phone chips to communicate to their human operators, certain levels being measured by its sensors, for a decision to be taken.

This conversation between machines is called machine-to-machine communication (M2M). Although this may seem like a great innovation for some people actually already have these interactions for years in the form of bar code, security sensors and other transparent interfaces. This communication model is called the "Internet of Things" or "Smart Cities". The principle of sensors and communication is the same, but now we can receive sensitive information intended to bring in a better quality of life, business agility and date information through the 'things'.

In the whole system, the sensors are external points of view that a user will have, being behind them, routers, servers, databases, applications, protocols, cloud storage and big data. This is a new form of interaction that can be considered as the evolution of the conventional Internet and will reach a larger share of users.

As with any IT project and infrastructure, its application depends on regulations and secure protocols, mainly in communication networks, which can become a short-term bottleneck point, since today they are overwhelmed by the huge number of devices that already use. It becomes a challenge to add another 50 Billion "things" that are expected to be connected in the world by 2020 , generating a very high traffic information.

We still have a number of challenges to be faced, such as network capacity of current data or new networks using unexplored radio frequencies, besides the interaction in a situation where the sensors use different patterns, making communication a 'tower Babel "that needs to be intelligible to all.

Once operational, this interaction of intelligent machines, will remedy most of large cities of problems, such as São Paulo, from urban mobility to the rigging supply goods companies and services consumed in large urban centers such as electricity, sanitation and other utilities. Also key will be to give greater efficiency to the logistics of cargo transportation, improving the city's supply conditions.

It will be necessary for our future life the intelligence offered by the machines and their very low response time. The machines undergoing a process of rapid evolution consolidate communication with each other independently. However the fear of man to lose ground to the machine persists and shows up today in more philosophical discussion than in the day-to-day tasks. The cheapening of the cost in operating and intellectual activities of the paper presents the problem of the modern world and man lives paranoia of having your invention chasing you and stealing your space.

\section{My computer wrote this without my help}

It seems science fiction and could even be part of a short story by Isaac Asimov, but it is a fact. A known algorithm detected an earthquake that happened in the western United States for Quakebot, which receives information from American Geological Survey (USGS) of any quake above 3.0 degrees. This algorithm is able to write short texts with a logical about the event and add some illustration as maps and even a brief headline.

Any given day, an earthquake hit the 4.4magnitude scale, the summary of the story was that this algorithm allowed to produce and sent an email to the Los Angeles Times with a prompt report which was received by Ken Schwencke, digital journalist and data producer, only depending on the journalist check the veracity of the facts and give the command to be published matter. Thus, the newspaper after eight minutes from fact gave the scoop (OBSERVATÓRIO DA IMPRENSA, 21/05/2014).

Stories like this are increasingly common nowadays and ultimately constitute arguments that make people believe that technology will replace the man, always packed for a little fantasy, which is natural.

Another episode that illustrates this problem took place in the US where two major competitors in the field of electronic commerce (e-commerce), decided to adopt algorithms to manage price of a book on animal training and suddenly, it was found that the book was costing a fortune. This occurred because the two algorithms were scheduled to raise the price of the book every time the concurrent promote a high, causing a spiral increases from the first attempt. Obviously those responsible came only notice the fact when the little book of pet training reached the stratosphere.

This fact allows us to redeem Asimov, who in 1950 claimed in his book I, Robot. "Not always mathematical symbols scrawled on paper are the most comforting protection against robotic reality" (ASIMOV, 1976:66) 
The confrontation between the man in the job functions and the machine to support the development of its functions, is intrinsic to the capitalist mode of production, already manifesting itself since it's beginning, at all stages of the Industrial Revolution. This, in the final instance comprises a process of exchange of human energy by mechanical energy and its full outbreak was only possible thanks to revolutionary innovations as the power loom (Dobb, 1971).

The Industrial Revolution, a process that became evident in the mid-eighteenth century, can be divided into three phases that mark the major waves of technological innovation:

- Stage 1 - 1750-1860 - The Industrial Revolution was the passage of commercial capitalism to industrial capitalism England was the first in the spread and development of the machines, the energy came from the steam and the main raw materials were coal and iron.

- Stage 2 - 1860 to 1960 - With the expansion industrial capitalism appears the orbit of finance capital and is the spread of manufactures to other nations like Belgium, Germany, France, who used the energy of Oil and Electric, and the steel the basic raw material.

- $\quad$ Phase 3 - 1960 to today - characterized by the development of information technology, also known as the Third Industrial Revolution. It is the era of microelectronics, biotechnology, robotics and nanotechnology. Holders' countries of expertise are the United States, Korea and Japan.

The first phase of the Industrial Revolution was marked by the appearance of the machines and the increase in large-scale production, eliminating somehow the craftsmanship. Another important point was the rural exodus and the emergence of the problems with unplanned urbanization, inadequate housing, lack of sanitation, health and poor hygiene, proliferating diseases such as bulbonic plague and smallpox.

The exploitation of labor reached the limits of human strength, with large working hours, low wages and unhealthy conditions of workers in coalmines and factories. Unemployment increased by leaps and bounds and the exploitation of labor, both women and child, permeated human life. Between the years 1811 and 1812 was born in England a movement called
Luddite, as opposed to technological progress promoted by the Industrial Revolution. The name of the movement comes from the name of one of its leaders, Ned Ludd and had to flag the question of the replacement of labor by machines. Known as "machine breakers," the group invaded factories and broke equipment in retaliation for the unemployment generated by them.

"Many workers were executed, which did not stop the movement gained huge expanse between 1811 and 1817, then known as" luddite "(Ned Ludd name you bored with your boss, broke hammered the workshop and this looms became legend symbol, and leader movement)." (COGGIOLA:19/06/2014) (Translation of authors)

The Luddite movement disappeared insofar as the first unions gained strength, known as trade unions. In the midst of this situation are born first questions against capitalism, the Utopian Socialism, whose exponent was Roberto Owen. In the second half of the nineteenth century, then comes the Scientific Socialism of Marx and Engels, who can establish a consistent criticism, whose maturity is proved by the subsequent efforts of the working class organization as well as the first major success of the proletarian revolution, 17 October 1917, the Bolshevik Revolution.

The extent of Marx's work is widely known, but we can identify some dates that allow locate in time the texts that contributed to promote great theoretical and ideological changes within a capitalist world already: German Ideology (1845-46), Party Manifesto communist (1848), to the critique of Political Economy (1859) and the Book I of The capital (1867). Was put to the scientific critique of capitalist mode of production, highlighting its contradictions, demonstrating unstable character and its subjection to the inevitable crises. The central contradiction was given by the antagonistic relationship between the capitalist class owns the means of production and the working class, dispossessed, he could only rely on the sale of their labor power for survival. Therefore, is very important to reflect on the central issue of this paper, highlighting the conflict between man and machine.

The world was no longer the same. The Communist Manifesto shows the world that humanity must seek the solution of problems arising from the exploitation of labor, such as poverty and poor living conditions in cities and in the countryside, where 
small farms had been expropriated by the advance of facing production to feed the booming market, fundamental to the advancement of capitalism.

According Vianna, between 1950 and 1960, occurred the spread and discussion of concepts and research all...

"a line of economists dependence, which, focusing on the same levels of macroeconomic analysis of Marx, emphasized thematically: the relationship between capital and labor; the genesis of technological progress; the formation of the working class; the primitive accumulation of capital". (VIANNA, 19/06/2014). (Translation of authors)

In its conclusions, Vianna strengthens the technological-economic and demographic factors, which treaties, he said, "with a teleological, global and homogeneous perspective of social and economic progress" (ibid), are more convenient to corroborate with the thought of the classical economists that to explain the heterogeneity of the period, showing the important changes promoted.

Turning to today, the cheapening of production costs remains an obsession, confirming the history and reinforcing the dilemma of capitalism. The "cost" is the main villain of capital in modern private organizations, and government. On the other hand, the technology excites million and as many scares. This is due to the fact of the facilities promoted by new technologies in almost all walks of life, but being realized through innovations that are encroaching on the land occupied by the classic human labor.

In order to contribute to the debate on the effects of technological progress on human life, then resume an important debate that takes place in the field of political economy: the prevalence or not of the Trend Declining profit rate Law (LTDTL) Marx.

\section{Trend down the law of in- come tax}

We will pass this section to address the TDPL, highlighting its theoretical basis, some positions that reject the theoretical elaboration of Marx and others who reject the criticism, being favorable to its acceptance as an immanent feature of capitalism, say by the way, very important in his critique of capitalism construction.

\subsection{The law as such}

The formulation of TDPL by Marx is simply magnificent and the immanent and contradictory nature of the capitalist mode of production, that subject to the repeated crises that its history cannot be denied. A mode of production, whose logic is embodied in the capital of the saga in profit and wins with him to keep alive his recovery process from the perspective of TDPL suffers from a congenital evil that threatens the object of this achievement. This cannot be dismissed as reflection in any of the analyzes of the phenomena that manifest themselves in capitalism of the universe, and the conflict between man and machine is one of those phenomena.

Of course, if we have conviction that TDPL is a theoretical construct that was born empty or emptied in historical time, we can make this omission on the TDPL and the conflicts arising from it. For this we have to be convinced effectively, but the debate that has accumulated in the literature on the subject, at least, is an indicator that the conviction to deny TDPL is not easy. More difficult is even when we indicators offered by the history of capitalism, which is also accumulating chapters that at least raise suspicions about the large presence of TDPL in its dynamics and all its effects on man. We will return to these effects in the section that conclusion.

We understand that TDPL offers the fundamentals of growing productivity and its exclusive nature regarding the workforce, more precisely, the participation of "work" in the production process under capitalism. We can start with a simple algebraic analysis based on the formula of the rate of profit in accordance with the value of the equation formulated by Marx, represented by the following expression, remembering that we are working in the size of production, in which the values of the components of value of the goods refer to hours of work, within the principle of the theory of labor value:

$$
\mathrm{VM}=\mathrm{c}+\mathrm{v}+\mathrm{m},(1) \text { being, }
$$

c - constant capital, comprising all inputs competing in the production of goods, from machinery, equipment and buildings to raw materials and auxiliary materials;

$\mathrm{v}$ - variable capital, which is the portion of the work that is paid; 
$\mathrm{m}$ - added value, which corresponds to the portion of the work that is not paid.

From equation (1) can be extracted from some important definitions:

$\mathrm{s}=\mathrm{m} / \mathrm{v}$, which indicates the rate of exploitation, that is, the unpaid labor, is the paid work.

$\mathrm{g}=\mathrm{w} / \mathrm{v}$, indicating the organic composition of capital, and the relationship between the constant capital and variable capital.

$p^{\prime}=m /(c+v)$, which indicates the profit of the capitalist, which is given by the ratio of added value and pound that is used to reach it, corresponding to constant capital and variable capital installments.

Promoting the $\mathrm{p}$ division 'by $\mathrm{g}$, we get the same profit rate expressing its relation to the organic composition of capital $(\mathrm{g})$, as follows:

$$
\mathrm{p}^{\prime}=\frac{\mathrm{s}^{\prime}}{\mathrm{g}+1}
$$

Examining (2) it is seen that the rate of profit positively varies the sampling rate $\left(\mathrm{s}^{\prime}\right)$ on the growth work, and moreover, is pressed down in the organic composition of capital (g) also increase. And here lies a core aspect of TDPL.

The rise in the organic composition of capital results in a more than proportional development of the portion related to the constant capital (c) with respect to the portion of variable capital $(\mathrm{v})$, which means in direct and simple terms, the replacement of man (work live) by constant capital (dead labor). It is the process that Marx calls "denial of living labor" resource used by the capitalist to increase your productivity, that is, its ability to extract more value of capital used in production, achieve higher profit, perform well, the dream cherished when started his business, and which can never be separated in their nights sleep. In the words of Marx, "thanks to the increasing use of equipment and capital stock in all its forms, the same number of workers is converted into products at the same time, and, with less work, a larger amount of raw materials and auxiliary "(Marx 1975: 214) (author's translation).

Eyeing the basket of eggs, trying to clog it, the capitalist, pressured by competition, ends up having to kill their chickens, progressively. According to Moraes (1996: 43):

"(...) Increasing the rate of capital gain, or work operation rate coexists with reducing the number of workers, ie, decreases the working mass set in motion by a given amount of capital. So even increase the rate of surplus value, the reduction of the magnitude of variable capital involved in the production process put in check the final behavior of the rate of profit. Thus, the denial of the work, taken as a wide character process, covering, even if not simultaneously all branches of capitalist production, but the main, inevitably resulting in an increase in the organic composition of capital, establishing a definitive meaning to the behavior the profit rate, which is declining." (Translation of authors)

One can not fail to mention that Marx, after presenting the TDPL in Chapter XIII of Book III (1975), devotes the next chapter (XIV) to highlight the search of capitalist production by means which are intended to circumvent the downward trend of the profit rate or, in the words of Marx himself the "causes that go against the law." Highlights how those causes or means, increased absolute and relative surplus value, the cheapening of constant capital, relative overpopulation, foreign trade and the establishment of joint stock companies. All these means, mitigate the effects of the law but do not solve the contradiction that gives rise to the downward movement of the profit rate, based on the contradiction between labor and capital, the latter responding to the pressure of competition, with the replacement of the man machine. However, according to Marx: "capitalist production constantly aspires to overcome their inherent limits, but can only overcome them by such means returning to stand against it, these same limits, but with greater force" (Marx 1975: 248) (translation of the author)

Concluding this subsection, let's be clear that there are two important effects generated by TDPL: a pressure to lower the rate of profit and a denial of living labor, therefore, an exclusion from the production process man, in favor of machinery in its various forms. The latter effect is the central theme of this article.

\subsection{Two major criticisms of TDPL}

One of the criticisms of TDPL recognized in the literature comes from a major US Marxist economist Paul Sweezy Malory, manifested in one of his works, 
Theory of capitalist development - principles of Marxist Economics Policy (1983), first published in 1942.

The criticism of Sweezy is based on a possibility of orientation in technological progress that may override the downward trend of the profit rate. It should be noted, without regard to disqualify criticism of Sweezy, who as mentioned above, Marx himself points the cheapening of constant capital as a contradictory tendency to "law", that is, the role of technological progress as capital resource for reverse this trend is laid.

According to Mantega (25/06/2014), criticism of Sweezy takes into account that the theoretical construction of Marx was based on a structure of capitalism competition, in which predominated the transition from manufacturing to devise-making, during which was very clearly the replacement of men by machines, it is living labor by dead labor. Capitalism of the twentieth century, assuming the monopolist, lives with new trends that could not be foreseen by Marx a century earlier.

Sweezy and his partner Paul Baran in another work, Monopoly Capital (1974), "bury" definitely the theoretical framework of Marx, denying the prevalence of "law of value". They admit that the environment of monopoly capitalism, big business, managing prices and emphasizing cost reduction as the main weapon in the competitive process, enable the survival indefinitely high profit rates.

A historical criticism of the law of downward trend of the profit rate is the "Okishio argument" (1961). This author could not imagine that the capitalists to adopt technologies that resulted in a reduction in the rate of profit. The core of the argument is that at the moment of making investment decisions, capitalists are guided by the cost criterion and not productivity. So, no matter what worker productivity increases, but the end result the cost falls. Within this reasoning, the capitalists refuse to employ a technology that increases productivity, if your additional cost not allows a reduction of the cost.

\subsection{In defense of TDPL}

Let this subsection counter arguments for prevalence of TDPL challenging criticism of Sweezy and Okishio.
The defense of TDPL is done by Belluzzo (1987), regarding the criticism of Sweezy. According to him, the change in orientation of technological progress as admitted by Sweezy, should result in very deep changes that could result in the elimination of contradiction that the decline in the rate of profit is. However, in all of his work, you cannot find any explanation about it even considers Belluzzo, there is no theoretical basis to give based Sweezy position. Belluzzo is surprised that Sweezy did not understand the work of Marx, the connection between the downward trend of the profit rate and the periodic crises of capitalism. Bolstering the defense Belluzzo, it recovers Aglietta (1979), for whom the crises are manifestations of the difficulties of the capital accumulation process, constitute the fullest confirmation of "law." Moreover, for this author, the controversy that has arisen around the TDPL only reflects a misunderstanding of the Marxist dialectic by economists who promote it.

For the refutation of "Okishio argument", we turn to Faria (1989), which raises two objections. The first one takes into account the behavior of wages, which, according to Faria, should express themselves in a basket of goods constant. As the post-war there was a real wage growth, especially in OECD countries, was stimulated the adoption of technologies called "progressive", that is, effectively resulting in an increase in the organic composition of capital ( $\mathrm{g}$ ).

A second objection by Faria, more forceful, raises the question of the sovereignty of inter competition acting upon the individual capitalist, and that ultimately decide on the choice of technology to be adopted. For the author, Marx would never have thought that economic life resulted merely from rational choices of economic agents, as understands and teaches the neoclassical tradition. (Ibid: 139).

Even toward the question "Okishio argument", it is a quotation from Marx elected by Faria to illustrate their understanding of the issue:

"No capitalist voluntarily applies a new method of production, however profitable it can be or however much they can increase the rate of surplus value, when it can decrease the rate of profit. But any new method of production cheapens the goods. The capitalist begins then selling them above their price of production and perhaps most of its value. Pockets the difference between their cost of production and the commercial price of all other 
commodities produced with a higher cost of production. It can do this because the working time socially necessary for the production of these products is greater than the working time that the new production method requires. Its production process is above the average of social production. However, competition is responsible for generalize it and submit it to the general law. Soon cometh the fall of the rate of profit - perhaps starting in the same branch of production, only to be leveled with the other branches - which is therefore absolutely independent of the will of the capitalist "(Marx 1975: 261) (translation of authors)

So close this section on TDPL, explaining some aspects of the controversy that surrounds it. Regardless of whether where is the truth about it, as we have said, is unforgivable not consider it important in the reflection that has as its object the investigation into the existence of a conflict between man and machine.

\section{Conclusion}

As we have seen above, the machines are already talking with the machines, exercise management activities; advance finally accelerated the man's workspace. We can imagine that one day a robot will knock on our door to deliver a match? For all that has happened, we can imagine so, but needless to wait for this moment since the advent of email and the features of the smart phone, have eliminated important part of the match that made the postman weight pouch.

There is no division, no window that can support the elbows and admire the scenery; we will not find human activity being hived off by technology. Who did not realize that their preferred doctor, which was once called "family doctor", delegated diagnosis, and ultrasound machines and tomography? There is no escape and would be a tour endless list the technical progress made. We already have enough for our reflection.

We cannot deny the ease and benefits that technology, in particular through a number of inventions, brought the man. In this case, we are talking of the man as an individual member of society, part of a whole. We cannot escape the question, and this whole, better?
Lessons of the most puerile of Economic Science gives us the flag to give an answer, we speak of "Sophistry composition". In economics, there are numerous examples showing that what is good for an economic agent, will not necessarily good for the whole. Let's just use one striking example:

When an individual makes a saving, is serving a healthy rule of budget planning, reserving value for future achievements that rejoice whole family, such as purchasing a car or a bigger house. However, a spread of the saving act as a precaution stimulated by a threat, or by voluntary acts simply can cause a macroeconomic effect that will reduce the multiplier of income, the effective demand, employment, finally, will negatively affect the pace of economic activity than will bring all its deleterious effects for all individuals, or for society.

Of course, the "Sophia composition" is not a theory itself, drawing on concepts residing in other theoretical elaborations, but serves as a warning, at least, compelling us to take very seriously the reflection on the conflict between the man and the machine, or more precisely, updating terminology, between man and technological advancement.

In this sense, we cannot fail to bring to our analysis, Jeremy Rifkin. It is the author of a revolutionary work that preaches radical changes in society, in contrast, draws an alternative to the ills of modern society, rammed by new technologies, within the limits of capitalism, protecting their fundamental institution, private property. However, the author does not shy away from the recognition of a characteristic of our time: the end of jobs. This is even the title of his important work (1995), in which advocates alternative "third sector" as a solution to accommodation of strong social exclusion caused by the deepening of technological advancement.

According to Rifkin, civilization, since its inception, was structured according to the work, but in the last decades of the twentieth century, it is clear that human labor is being eliminated from the production process. Says the author:

"In less than a century, the work 'mass' in the market sector will probably be eliminated in almost all industrial nations. A new generation of sophisticated information and communication technologies is being introduced rapidly in various work situations. Intelligent machines are replacing human beings in countless tasks, forcing millions of office 
workers and laborers for the queues of unemployment, or worse, to the ranks of jobless." Rifkin (ibid: 3) (translation of authors)

Grow the ranks of unemployed and underemployed increases the quota in the developed and developing nations are also facing technological unemployment as a result of the action of multinational companies that deploy production facilities using the latest technology. Young people show their frustration with antisocial behavior, while the old it is nothing more than the resignation. It recognizes the author: "Life as we know it is changing in a fundamental way" (ibid: 5).

Within this picture comes to light the third sector proposal, as output to absorb the large and growing phalanx of unemployed, whose work force would be employed in volunteer work, social and focused nature also the infrastructure works that would eliminate bottlenecks to improve the lives of communities. A fund to which portion of taxes on high-tech products would be the main source of funding Third Sector. Anyway, the "guilty" would help pay the social prejudice.

To ensure the principle of impartiality in the analysis, we turn now to an author whose works fall within the Marxist theoretical matrix, Robert Kurz, albeit with a view to update the Marxist theory in the light of the changes that capitalism has experienced since his claim to production mode, the Industrial Revolution. His pessimism about the future of capitalism, can be evaluated in the following passage:

"Mass unemployment, which first appeared temporarily during the global economic crisis, has become a permanent problem of world society. Western countries, thanks to its historical advantage and its increasingly advanced productivity, could "export", at least in part, this problem; but the overall situation of the global system of commodity production has become precarious. This everincreasing productivity, exceeding the absorptive capacity of the production of goods, could not be without catastrophic repercussions on recuperative processes of primitive accumulation." (KURZ, 06/24/2014) (translation of authors)

And his most impressive work, the collapse of modernization - the collapse of socialism barracks to the crisis of the world economy (1993), the author states that the process of automation, amazing in all sectors of activity, would finally creating the conditions for overcoming society based on human labor. The massive increase in productivity would be the first time in the history of capitalism, reducing the absolute number of workers.

According to the International Labour Organisation (ILO), the world gained 4 million unemployed in 2013 (ONUBR, 27.6.2014) and estimates are pessimistic for the next four years. Any source consulted did not deny the stocky unemployment numbers anywhere in the world, including in China, where half of the individuals with higher education are jobless, the same rate that affects young Spaniards. However, the media, always and everywhere, controlled by the groups that have the political leadership, assigns numbers uncomfortable cyclical performance of the economies, adding even as explanatory causes, the erroneous conduct of economic policy. This is another element that can throw an opaque veil and confuse the results of reflection we set out on the conflict between man and machine, but we cannot fail to mention it. It's an ingredient of a complex subject.

This complexity cannot intimidate us to express a conclusion. From the above, we affirm with serenity, that there are strong indications that the machine and innovation, in the broad sense, representing and materializing technological progress, is "good for man, but is a threat to men." 


\section{References}

Aglietta, M. Regulation y crisis del capitalismo. Madrid: Siglo Veintiuno Editores, 1979.

Asimov, I. Eu, robô: São Paulo: Editora Edibolso S.A. 3ªd. - 1950.

Baran, P. A. and Sweezy P. M. Capitalismo monopolista. Rio de Janeiro: Zahar Editores. 1974.

Belluzo, L. G. M. Valor e capitalismo: um ensaio sobre a Economia Política. São Paulo: Ed. Bienal, 1987.

Dobb, Maurice A evolução do capitalismo. Rio de Janeiro: Zahar Editores. 1971.

Drucker, P.F. Fronteiras do amanhã. Rio de Janeiro: Fundo de Cultura, 1964.

Faria, L. A. E. O retorno da crise e da controvérsia. In: Desvendando a Espuma: reflexões sobre crise, regulação e capitalismo brasileiro. Porto Alegre: Fundação de Economia e Estatística, 1989.

Marx, K. O capital. Livro III. 2a ed. México: Fondo de Cultura Económica. 1975.

Moraes, A.C. Capitalismo, crise e Estado. PhD thesis submitted to the Department of Social Sciences from PUC-SP. 1996.

Okishio, N. Technical changes and the rate of profit. Kobe university economic review. $\mathrm{n}^{\circ}$ 7, 1961, pp. 91-2.

Rifkin, J. O fim dos empregos. São Paulo: Makron Books. 1995.

Sweezy, P. M. Teoria do desenvolvimento econômico - princípios de Economia Política marxista. São Paulo: Abril Cultural, 1983.

\subsection{Web references}

Coggiola, O. O movimento operário nos tempos do manifesto comunista. Available in: http://www.pucsp.br/cehal/downloads/textos/ATT00599.pdf. Access: 19/06/2014.

Mantega, G. A lei da taxa de lucro: a tendência da queda ou a queda da tendência? Available in: http://www.cebrap.org.br/v2/files/upload/biblioteca_virtual/a_lei_da_taxa_de_lucro.pdf. Acesso em 25/06/2014.

Kurz, R. O fracasso da modernização. Available in: http://obeco.no.sapo.pt/livro_colapsom.html. Acesso em 24/06/2014.

O colapso da modernização - da derrocada do socialismo de caserna à crise da economia mundial. São Paulo: Editora Paz e Terra, 1993.

Observatório da imprensa. Available in: http://www.observatoriodaimprensa.com.br/news/view/_ed792_o_robo_que_apura_e_escreve_sobre_terremo to. Access: 21/05/2014.

ONUBR. Available in: http://www.onu.org.br/. Access: 27/06/2014.

Vianna, A. M. - Revolução Industrial: um breve ensaio crítico. Available in: http://www espacoacademico.com.br/090/90vianna.pdf. Access: 19/06/2014. 